Walenty Poczta

Arkadiusz Sadowski

\title{
Bezpieczeństwo żywnościowe i oddziaływanie środowiskowe rolnictwa w europejskich krajach transformacji ustrojowej
}

Streszczenie: Artykuł jest poświęcony problematyce relacji pomiędzy rolnictwem i środowiskiem, rozpatrywanych w kontekście przemian ustrojowych, jakie nastąpiły w Europie Środkowej i Wschodniej. Na tle ogólnych rozważań na temat znaczenia czynników przyrodniczych i antropogennych (w tym głównie polityki) badaniom zostały poddane europejskie kraje postkomunistyczne, z których część przystąpiła do UE, a część jest poza nią. Tłem badań były państwa UE-15 oraz średnie wartości dla świata. Analizy objęły okres 1993-2013, a więc lata, kiedy nieprzerwanie istniały wszystkie omawiane kraje. Posługując się autorską metodyką, wskazano zmiany w zakresie produktywności rolnictwa (rozumianej jako ilość wytworzonej energii rolniczej w przeliczeniu na 1 ha) oraz jego oddziaływania na środowisko, określonego poprzez wielkość emisji gazów cieplarnianych. W wyniku przeprowadzonych analiz wskazano na zasadniczy wpływ czynnika demograficznego oraz przyrodniczego na intensywność produkcji rolniczej oraz skalę emisji. Możliwość zaspokojenia bezpieczeństwa żywnościowego zależy natomiast od stosowanych technologii, a pośrednio od poziomu ekonomicznego rozwoju kraju. Zwrócono uwagę na odmienne podejście do rozwoju rolnictwa w krajach transformacji ustrojowej będących członkami UE oraz pozostającymi poza nią. W obszarze zrównoważenia środowiskowego zauważono największe postępy dokonane przez kraje, które po zmianie ustroju nie przystąpiły do UE. W tym kontekście podjęto rozważania na temat pozapolitycznych czynników kształtujących relacje pomiędzy rolnictwem i środowiskiem.

Słowa kluczowe: europejskie kraje transformacji ustrojowej, bezpieczeństwo żywnościowe, zrównoważony rozwój rolnictwa, WPR.

Prof. dr hab. Walenty Poczta, Uniwersytet Przyrodniczy w Poznaniu, Wydział Ekonomiczno-Społeczny, ul. Wojska Polskiego 28, 60-637 Poznań, poczta@up.poznan.pl; dr hab. Arkadiusz Sadowski, Uniwersytet Przyrodniczy w Poznaniu, Wydział Ekonomiczno-Społeczny, ul. Wojska Polskiego 28, 60-637 Poznań, sadowski@up.poznan.pl. 


\section{Uwagi wstępne}

Produkcyjne, ekonomiczne, polityczne i społeczne aspekty związane z kształtem rolnictwa w poszczególnych częściach świata są determinowane przez wiele czynników, które najogólniej można podzielić na środowiskowe i antropogeniczne. Jest to o tyle oczywiste, że rolnictwo w założeniach polega na wzajemnej interakcji natury i ludzkiej inwencji. Przyroda wpływa na możliwe (lub opłacalne ekonomicznie) kierunki produkcji i ich fizyczne rozmiary. Jakość gleb, przebieg opadów i zmiany temperatur w ciągu roku w znacznej mierze decydują, co i w jakiej skali w danym miejscu może być produkowane. Rolą człowieka jest z kolei takie przekształcanie przyrody, aby, ujmując rzecz w największym skrócie, zwiększyć produktywność ziemi poprzez stosowanie rozmaitych ulepszeń, od melioracji poczynając, a na zastosowaniu odpowiednich maszyn kończąc. Patrząc na problem z punktu widzenia bezpieczeństwa żywnościowego rosnącej populacji świata, działania te są uzasadnione, a wręcz konieczne. Zasadnicze niebezpieczeństwo tkwi jednak w priorytetowym traktowaniu celów bieżących w stosunku do długookresowych. Często są one sprzeczne (Poczta, Baer-Nawrocka 2016). Jest przy tym oczywiste, że te pierwsze mają głównie charakter ekonomiczny, a te drugie środowiskowy (Czyżewski, Czyżewski 2016). Takie sformułowanie priorytetów jest przy tym charakterystyczne nie tylko dla producentów rolnych, ale ogólnie dla przedsiębiorców, którzy chcąc utrzymać się na rynku, muszą reagować na bodźce dopływające z niego w danym momencie, co odbywa się nieraz kosztem ważnych celów długookresowych. Rozwiązanie tego konfliktu możliwe jest między innymi na gruncie dobrze prowadzonej polityki (Sadowski 2009), aczkolwiek należy też poszukiwać innych rozwiązań, co będzie przedmiotem dalszych rozważań. Równie ważna jest wielopokoleniowa perspektywa funkcjonowania gospodarstw rolnych (głównie indywidualnych), które poza realizacją bieżących celów ekonomicznych muszą troszczyć się o zachowanie lub poprawę rolniczej przestrzeni produkcyjnej, w tym głównie gleby, będącej podstawą rodzinnego biznesu (Sadowski 2012; Sadowski et al. 2015; Sadowski et al. 2016). Rozpatrując problem interakcji rolnictwa i środowiska, należy uwzględnić ponadto społeczny aspekt zagadnienia, czyli fundamentalną rolę tego sektora w zapewnieniu bezpieczeństwa żywnościowego. Oznacza to, że (pomijając nawet mikroekonomiczne interesy rolników) społecznym i państwowym priorytetem zawsze będzie wytworzenie odpowiedniego wolumenu produkcji, a dbałość o jakość środowiska praktycznie możliwa jest dopiero przy zapewnieniu bezpieczeństwa żywnościowego. Oczywiście pewne proekologiczne działania sprzyjają poprawie wyników produkcyjnych oraz ekonomicznych. Wymienić tu można chociażby właściwe nawożenie, poprawiające produktywność gleby, czy większą wydajność przy zachowaniu zasad dobrostanu zwierząt. Niemniej jednak 
w przypadku problemów wyżywieniowych pozytywny wpływ na środowisko jest raczej „produktem ubocznym” działań proporodukcyjnych niż celem samym w sobie.

Nadmienić przy tym trzeba, że możliwa skala wspomnianych ulepszeń zależna jest nie tylko od indywidualnej wiedzy i umiejętności rolnika, ale także (a może nawet przede wszystkim) od sposobu organizacji społeczeństwa, w tym głównie od ustroju państwa i prowadzonej polityki, nie tylko rolnej. Przede wszystkim państwo odgrywa zasadniczą rolę w kształtowaniu struktury agrarnej, która to z kolei mocno oddziałuje na kierunki produkcji, stosowane techniki wytwórcze, w tym możliwość wprowadzenia innowacji, wpływając tym samym na kształt rolnictwa danego kraju. W ostatnim czasie coraz większego znaczenia nabierają przepisy odnoszące się do ochrony środowiska oraz zdrowotnej jakości surowców rolnych.

Jeśli uwzględni się znaczącą rolę polityki w kreowaniu obrazu rolnictwa danego kraju, to logiczne będzie przyjęcie założenia, że zmiany ustroju będą miały wpływ na kierunek i wielkość produkcji rolnej, a także na strukturę agrarną w wielu jej wymiarach. Dodatkowo należy uwzględnić także to, że fundamentalne zmiany ustrojowe niemal zawsze dokonują się w warunkach kryzysu ekonomicznego, będącego skutkiem niewydolności dotychczasowych rozwiązań ustrojowych. Kryzysy te $\mathrm{z}$ natury rzeczy dotykają rolnictwo, jako sektor uzależniony od dostaw środków produkcji. Spadek produkcji rolnej, problemy z zaopatrzeniem w produkty spożywcze oraz wzrost ich cen są też jednymi z ważniejszych i na co dzień najbardziej widocznych jego wymiarów.

Rzecz staje się tym bardziej znamienna, jeśli chodzi o ustrój realnego socjalizmu. Nie wchodząc w szczegóły jego specyfiki jako całości oraz lokalnych odmian, na potrzeby niniejszego opracowania należy skupić się na jego istocie, wyrażającej się $\mathrm{w}$ przejęciu przez aparat państwowy kontroli nad czynnikami produkcji, w tym także nad tak fundamentalnym dla rolnictwa czynnikiem jak ziemia. W większości krajów socjalistycznych, wkrótce po dokonanej reformie rolnej, polegającej na przekazaniu małorolnym chłopom ziemi obszarniczej, rozpoczęto tworzenie państwowych lub spółdzielczych (w praktyce quasi państwowych) dużych przedsiębiorstw rolniczych (Szpak 2007; Poczta, Sadowski, Średzińska 2008; Sadowski, Czubak 2012). Wyjątek w tym zakresie stanowiły Polska i Jugosławia. W odniesieniu do omawianej tematyki równie ważna była dominująca ścieżka przemian dokonywanych po upadku ustroju socjalistycznego. W takich krajach jak Czechy, Słowacja czy w znacznym zakresie Węgry dokonano przemian własnościowych, zachowując jednak w dużej mierze wielkoobszarowy charakter gospodarstw rolnych powstałych $\mathrm{z}$ dawnych przedsiębiorstw państwowych i spółdzielczych (Majerova et al. 2016). Podobnie rzecz się miała w krajach byłego ZSRR, poza państwami bałtyckimi (Dzun, Tereszczuk 2009; Rowiński 2011). W innych krajach postkomunistycznych zmiana ustroju rolnego dokonała się głównie poprzez zwrot ziemi 
byłym właścicielom (Halamska 1998; Tudor 2016), co ostatecznie skutkowało rozdrobnieniem struktury agrarnej. Sytuacja w Polsce i krajach byłej Jugosławii jest pod tym względem podobna, aczkolwiek skala przemian była tam mniejsza o tyle, o ile mniejsze było znaczenie tzw. sektora uspołecznionego w poprzednim okresie.

Dla rozwoju rolnictwa i jego środowiskowego oddziaływania ważny był też dalszy kierunek przemian systemowych, polegający na objęciu tego sektora regulacjami Wspólnej Polityki Rolnej Unii Europejskiej. Spośród krajów postkomunistycznych tylko niektóre przystąpiły do tego ugrupowania. Większość państw byłego ZSRR (poza krajami bałtyckimi) i byłej Jugosławii (poza Słowenią i Chorwacją) ma status państw kandydujących (Jankowska 2016) lub są poza ugrupowaniem.

Przedstawione powyżej dwa fundamentalne wydarzenia (upadek realnego socjalizmu i przystąpienie do UE) miały przede wszystkim wpływ na kształt państwa i społeczeństwa, rozumianych jako całość, aczkolwiek również przyczyniły się do przemian rolnictwa, także w jego środowiskowym wymiarze. Zmiana stosunków własności i poddanie produkcji rolniczej wymogom racjonalności rynkowej przyczyniły się do stosowania bardziej oszczędnych (także w znaczeniu środowiskowym) technik wytwórczych, tym bardziej że posocjalistyczne przemiany odbywały się w warunkach niekorzystnych relacji cenowych. W innym kierunku, ale także związanym ze zamianami sposobów wytwarzania, prowadziła dekompozycja organizacyjna dużych uspołecznionych przedsiębiorstw rolniczych. Wspólna Polityka Rolna wiązała się z kolei z trzema ważnymi aspektami. Pierwszy z nich to akcesja krajów posocjalistycznych do wspólnego rynku i konieczność konkurowania na nim. Drugi to objęcie sektora rolnego wsparciem finansowym, gdzie poszczególne instrumenty były nakierowane na różne cele, $\mathrm{w}$ tym głównie na poprawę dochodowości gospodarstw, ich modernizację czy w końcu na ochronę środowiska. Inaczej jednak niż w państwach UE-15 złożoność potrzeb w zakresie rolnictwa i obszarów wiejskich uniemożliwiała skupienie środków finansowych na ściśle określonych priorytetach (Sadowski, Czubak 2013). Trzeci czynnik to objęcie rolnictwa regulacjami w zakresie ochrony środowiska. Nadmienić przy tym trzeba, że wszystkie wymienione wyżej czynniki strukturalne, takie jak dominująca forma własności, przeciętna wielkość gospodarstwa, wyposażenie w kapitał i związane z tym techniki wytwórcze mają fundamentalne znaczenie dla możliwości realizacji podstawowej funkcji rolnictwa, jakim jest zaspokojenie bezpieczeństwa żywnościowego, ale także na jego środowiskowe zrównoważenie.

\section{Cel i zakres badań}

Celem opracowania jest określenie ewolucji w zakresie bezpieczeństwa żywnościowego oraz oddziaływania na środowisko europejskich krajów postsocjalistycznych, 
z uwzględnieniem tych, które od 2004 r. przystępowały do Unii Europejskiej, i tych, które nie są jej członkami. Kierunek i skala przemian została przedstawiona na tle państw UE-15 oraz średniej dla świata, co w zamyśle ma wskazać oddziaływanie Wspólnej Polityki Rolnej na poszczególne parametry. Ze względu na to, że znaczna część analizowanych państw powstała na skutek rozpadu byłego ZSRR, Jugosławii i Czechosłowacji, czasowy zakres analizy obejmuje lata 1993-2013, a więc pełen okres dostępności danych statystycznych dla współcześnie funkcjonujących krajów. Zgodnie z przyjętymi założeniami i celami, do badań włączone zostały wszystkie kraje UE-15 oraz byłe kraje gospodarki centralnie planowanej, które obecnie są jej członkami (stanowiące tzw. UE-12). Nie uwzględniono więc Cypru i Malty. Spośród krajów, które w latach 90. zmieniły ustrój polityczny i ekonomiczny i dotychczas nie przystąpiły do UE, uwzględnione zostały: Albania, Bośnia i Hercegowina, Białoruś, Mołdawia, Macedonia oraz Ukraina. Badaniami nie zostały objęte natomiast państwa powstałe po rozpadzie ZSRR leżące w Azji, w tym także Federacja Rosyjska. Podejście takie zostało podyktowane odmiennymi przyrodniczymi uwarunkowaniami produkcji rolniczej, które potencjalnie mogły utrudnić identyfikację ekonomicznych i przyrodniczych uwarunkowań dokonanych przemian.

\section{Metodyka}

Opracowanie jest nakierowane na jednoczesną ocenę produktywności rolnictwa poszczególnych analizowanych krajów i ich oddziaływania na środowisko. Dlatego też podstawowe znaczenie w podjętych analizach mają dwie zmienne, określające poziom produkcji oraz wpływ na zmiany klimatyczne.

Pierwsza z nich, wskazująca w syntetyczny sposób na zdolność rolnictwa do zaspokajania jego podstawowej, wyżywieniowej funkcji, to ilość wytworzonej energii rolniczej ${ }^{1}$. Zmienna ta nie jest publikowana w światowych bazach, stąd została oszacowana, z wykorzystaniem następującego algorytmu:

$$
\sum \mathrm{Ew}=\sum_{i=1}^{n} E s_{i} * P * W_{i}
$$

gdzie:

Ew - ilość energii wytworzonej w rolnictwie (kcal/kraj), $E s_{i}$ - spożycie energii i-tego produktu rolniczego (kcal/osoba), $P$ - liczba ludności (osoby/kraj), $W_{i}$ - współczynnik samowystarczalności dla i-tego produktu.

\footnotetext{
1 Szczegółowe założenia przyjętej metodyki są zawarte w Sadowski 2017.
} 
gdzie:

$$
\mathrm{W}_{\mathrm{i}}=\frac{P_{i}}{Z_{i}}
$$

$P_{i}$ - produkcja i-tego produktu (t/kraj),

$Z_{i}$ - krajowe zużycie i-tego produktu (t/kraj).

Do szacowania ilości energii wyprodukowanej przez rolnictwo wykorzystano między innymi wybrane elementy ilościowego bilansu żywności (food balance), określonego dla poszczególnych produktów zgodnie z metodyką FAO. Celem takiego podejścia było sprowadzenie wielkości produkcji rolniczej (zarówno roślinnej, jak i zwierzęcej) do jednej, uniwersalnej jednostki energetycznej.

Drugą zasadniczą zmienną, wskazującą na skalę oddziaływania na środowisko, stanowi wielkość emisji rolniczych gazów cieplarnianych. Dane w tym zakresie zostały pozyskane bezpośrednio dla poszczególnych krajów z bazy FAOSTAT. Wykorzystanie obu naturalnych mierników pozwoliło na przeprowadzenie analizy efektywności produkcyjno-środowiskowej, gdzie po stronie efektu (produkcji) znajduje się ilość wytworzonych przez rolnictwo kilokalorii, a po stronie nakładów (środowiskowych „kosztów”), wielkość wyemitowanych gazów cieplarnianych. Należy w tym miejscu zaznaczyć, że realna gospodarka działa na podstawie rachunku ekonomicznego, wyceniającego nie tylko (w sytuacji pełnego bezpieczeństwa żywnościowego - nie przede wszystkim) wartość energetyczną produktów rolniczych. Niemniej jednak na potrzeby niniejszego opracowania zdecydowano się na wykorzystanie wyprodukowanych kilokalorii, przyjmując, że jest to obiektywny miernik podstawowej funkcji rolnictwa, jaką jest dostarczanie energii dla ludzkiego organizmu. Poza wymienionymi, podstawowymi zmiennymi, wykorzystano także inne mierniki, niezbędne dla określenia demograficznych oraz przestrzennych uwarunkowań rozwoju rolnictwa. Do najważniejszych zaliczyć można powierzchnię kraju i użytków rolnych oraz liczbę mieszkańców. Wszystkie one zostały zaczerpnięte $\mathrm{z}$ bazy FAOSTAT.

\section{Wyniki}

Demograficzne, przyrodnicze i przestrzenne uwarunkowania rolnictwa

Rolnictwo jest specyficznym sektorem gospodarki, wymykającym się często prawidłowościom charakterystycznym dla innych rynków, jednakże podlega ono powszechnemu prawu popytu i podaży. Rozpatrując zagadnienie na poziomie najbardziej podstawowym, to znaczy z pominięciem takich czynników jak preferencje kulinarne poszczególnych społeczeństw, ceny produktów spożywczych, 
stopień ich przetworzenia czy zamożność konsumentów, zasadniczym czynnikiem kształtującym popyt jest wielkość populacji i jej potrzeby konsumpcji żywności. Założenie takie można przyjąć, zważywszy, że niemal każdy człowiek jest konsumentem surowców rolniczych, szczególnie jeśli zagadnienie to rozpatruje się na poziomie spożytych kilokalorii.

Czynnik demograficzny został określony na podstawie gęstości zaludnienia, analizowanej na poziomie badanych grup państw (rys. 1). Nadmienić należy, że na tę zmienną wpływa szereg czynników o charakterze przyrodniczym (np. żyzność gleb, występowanie klęsk żywiołowych), politycznych (głównie stabilność systemu oraz łatwość migracji) oraz ekonomicznych (np. możliwość znalezienia zatrudnienia). W analizowanym okresie największą gęstością zaludnienia charakteryzowały się kraje UE-15, przy lekkiej tendencji wzrostowej tego parametru. Mniejszą gęstość zaludnienia wykazały postkomunistyczne kraje UE-12, gdzie jednocześnie nastąpił niewielki jego spadek, wywołany małym przyrostem naturalnym oraz emigracją, ułatwioną zwłaszcza po okresie akcesji. Podobna sytuacja miała miejsce w krajach postkomunistycznych, które nie przystąpiły do UE. Tam gęstość zaludnienia jest mniejsza niż w UE-12, lecz także widoczne są tendencje spadkowe. We wszystkich omówionych przypadkach wielkość tego parametru jest jednak znacznie większa od średniej światowej, co wynika bezpośrednio z relatywnie wysokiej zamożności krajów europejskich (rozpatrując rzecz w skali świata, zarówno tych ze wschodu, jak i zachodu kontynentu), a pośrednio także z wysokiej produktywności ziemi,

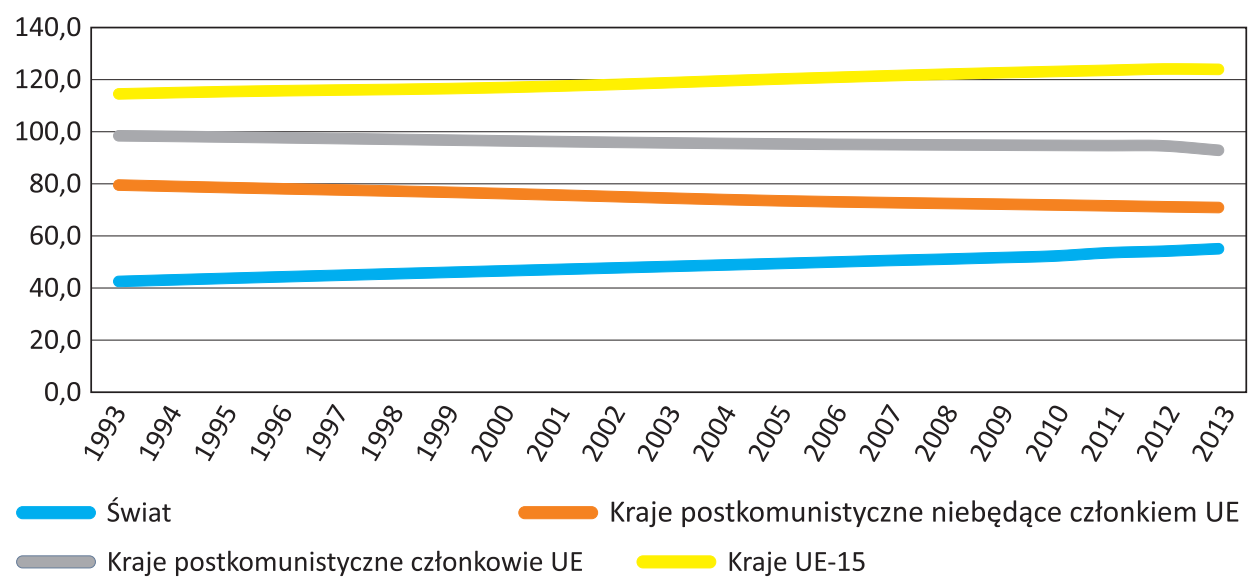

Rysunek 1. Gęstość zaludnienia (osoby $/ \mathrm{km}^{2}$ )

Figure 1. Density of population (pers. $/ \mathrm{km}^{2}$ )

Źródło: obliczenia własne na podstawie faostat.fao.org.

Source: Own calculation based on faostat.fao.org. 
umożliwiającej zaspokojenie bezpieczeństwa żywnościowego dla dużej populacji. Równie ważne z punktu widzenia oceny produktywności rolnictwa jest to, że wszystkie grupy w analizowanym okresie cechowały się (z uwzględnieniem opisanych niewielkich zmian) stabilnością w zakresie liczby ludności, co odróżniało je od reszty świata, gdzie nastąpił wzrost populacji.

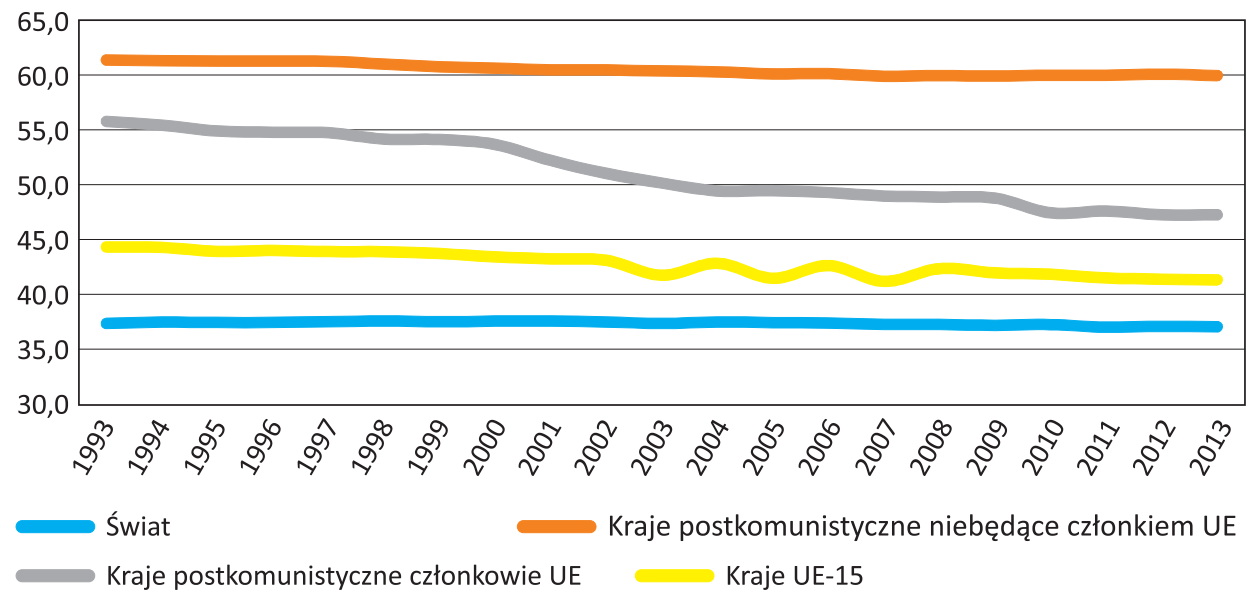

Rysunek 2. Udział użytków rolnych (powierzchnia ogółem = 100)

Figure 2. Share of agricultural land (total area $=100$ )

Źródło: obliczenia własne na podstawie faostat.fao.org.

Source: Own calculation based on faostat.fao.org.

Możliwości zaspokojenia potrzeb wyżywieniowych poszczególnych społeczeństw określa w największym skrócie areał ziemi przeznaczonej na cele rolnicze oraz jej produktywność. Europa, jak zostało to już wspomniane, posiada znaczne zasoby urodzajnej ziemi, co między innymi wpłynęło na sukces cywilizacyjny krajów z tego kontynentu. Zarówno państwa UE-15, jak i postkomunistyczne kraje UE-12 cechują się wysokim udziałem użytków rolnych (rys. 2), z tym tylko, że w tym drugim przypadku nastąpił dość znaczny spadek areału. Wynikać to może z przemian dokonanych nie tylko w rolnictwie, lecz także w całej gospodarce, skutkującej spadkiem opłacalności produkcji, a co za tym idzie rezygnacją $\mathrm{z}$ uprawy najmniej produktywnych gruntów. Udział ziemi rolniczej jest natomiast najwyższy w krajach postkomunistycznych niebędących członkami UE, co może mieć znaczący wpływ na potencjalne zdolności konkurencyjne, szczególnie jeśli uwzględni się to, że państwa te są zlokalizowane w tej samej strefie klimatycznej co większość krajów UE, a więc wytwarzają podobne surowce rolnicze. 


\section{Bezpieczeństwo żywnościowe}

Powierzchnia wyżywieniowa wynika bezpośrednio (matematycznie) z liczby ludności oraz areału użytków rolnych. Stanowi ona ważny element określający bezpieczeństwo żywnościowe, aczkolwiek nie determinuje go ostatecznie, szczególnie w warunkach współczesnego rolnictwa, gdzie większe znaczenie odgrywa produktywność ziemi. Największa powierzchnia użytków rolnych przypadająca na osobę (rys. 3) cechuje kraje postkomunistyczne, niebędące członkami UE. Od początku XXI wieku jest to więcej niż średnia światowa. Najmniejszą powierzchnię wyżywieniową posiadają kraje UE-15, aczkolwiek dla wysokowydajnego rolnictwa zachodniej i południowej Europy nie stanowi to zagrożenia bezpieczeństwa żywnościowego. Wszystkie trzy badane grupy różnią się jednak od reszty świata względną stabilnością, co wynika z niewielkich zmian tak w areale UR, jak w wielkości populacji. Dotyczy to także krajów UE-12, gdzie nastąpił ubytek zarówno ludzi, jak i ziemi rolniczej. W skali globu sytuacja jest inna - na skutek wzrostu populacji powierzchnia wyżywieniowa zmalała, co, uwzględniwszy niski poziom rozwoju znacznej części krajów, może budzić niepokój.

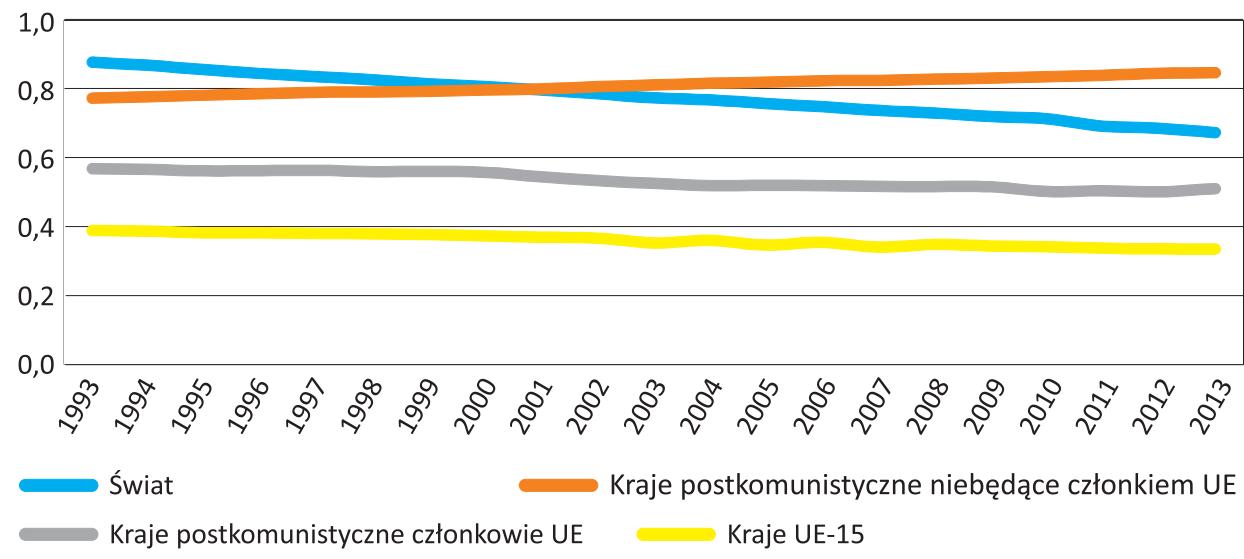

Rysunek 3. Powierzchnia wyżywieniowa (ha UR/os.)

Figure 3. Alimentation area (ha UAA/pers.)

Źródło: obliczenia własne na podstawie faostat.fao.org.

Source: Own calculation based on faostat.fao.org.

Produktywność ziemi stanowi podstawowy aspekt bezpieczeństwa żywnościowego, a jej wielkość zależy od naturalnej żyzności gleby, dokonywanych ulepszeń i inwestycji wykonywanych przez gospodarstwa oraz od stosowania odpowiedniej technologii. Nadmienić trzeba, że często wymienione czynniki wzajemnie na siebie 
wpływają, gdyż dokonywanie ulepszeń jest tym bardziej uzasadnione ekonomicznie, im bardziej urodzajny jest grunt, na którym się to robi. Oczywiście możliwe są sytuacje, gdy kraj dysponuje żyznymi gruntami, jednakże z powodu niskiego poziomu rozwoju rolnictwo nie jest $\mathrm{w}$ stanie prowadzić wydajnej produkcji.

Wymienione przyrodnicze i ekonomiczne czynniki spowodowały, że spośród analizowanych grup najbardziej wydajne (wydajność jest tu określona przez syntetyczny miernik, jakim jest ilość kcal/ha UR) jest rolnictwo krajów UE-15 (rys. 4). Co równie znamienne, wielkość ta pozostawała w całym badanym okresie na niemal niezmienionym poziomie, co wynikać może z dwóch zasadniczych powodów. Po pierwsze, relatywnie niewielka była presja popytowa, wynikająca ze wzrostu populacji. Przy braku problemów żywnościowych w Europie Zachodniej utrzymanie produkcji na odpowiednio wysokim poziomie było uzasadnione zarówno ekonomicznie, jak i etycznie. Po drugie, wpływ na ten stan rzeczy mogła mieć Wspólna Polityka Rolna, która była nakierowana na ekstensyfikację produkcji, żeby wspomnieć tylko takie narzędzia, jak kwoty produkcyjne, programy zalesieniowe i rolnośrodowiskowe, czy w końcu dobrowolne i przymusowe odłogowanie ziemi. W postkomunistycznych krajach UE-12 przeciętna produktywność ziemi była znacznie niższa, aczkolwiek wyższa od średniej światowej. W przypadku tej grupy charakterystyczny jest wzrost dokonany w analizowanym okresie. Przyczyn tego zjawiska należy poszukiwać zarówno w potrzebie odrobienia zaległości po okresie realnego socjalizmu, jak i w możliwościach, jakie stworzyła Wspólna Polityka Rolna, oferująca szczególnie swoim nowym członkom środki z II filara, przeznaczone na

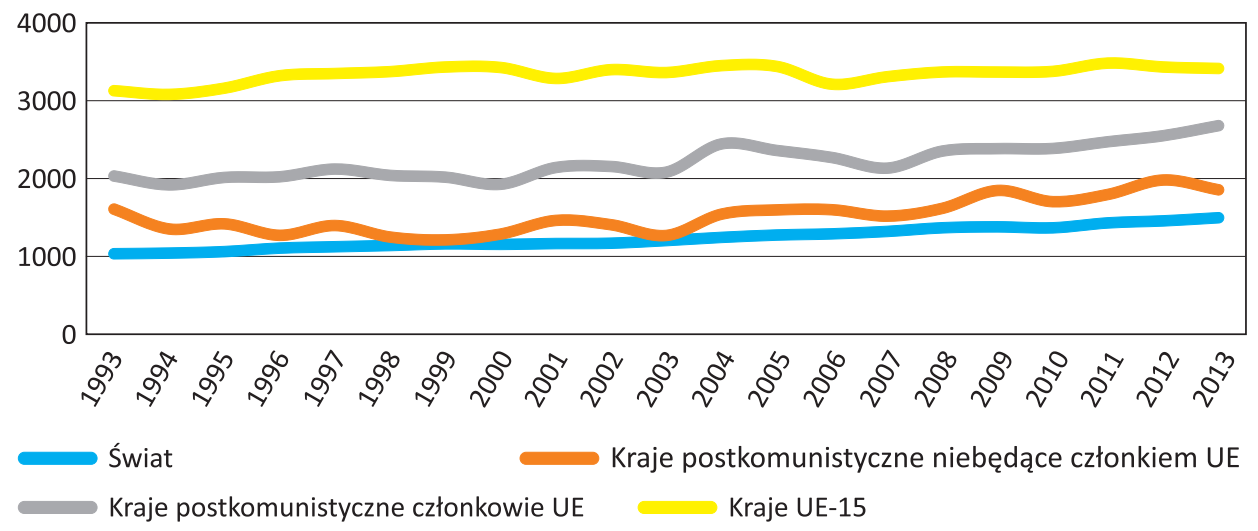

Rysunek 4. Produkcja energii rolniczej (tys. kcal/ha UR)

Figure 4. Production of agricultural energy (thousand $\mathrm{kcal} / \mathrm{ha}$ UAA)

Źródło: obliczenia własne na podstawie faostat.fao.org.

Source: Own calculation based on faostat.fao.org. 
modernizację gospodarstw. Dużą rolę odegrały też przekształcenia strukturalne idące w kierunku koncentracji produkcji (a w konsekwencji do wzrostu produktywności jako skutku poprawy wyposażenia kapitałowego) oraz świadomość potrzeby spełnienia wymogów konkurencyjności w stosunku do rolnictwa państw UE-15. Nie powinno w tym momencie zaskakiwać, że Wspólna Polityka Rolna w obu subgrupach przyniosła nieco odmienne skutki. Wynikało to z różnych wartości bazowych, dotyczących różnych aspektów rolnictwa, w tym także jego produktywności. Różnice te przekładały się z kolei na odmienne priorytety w zakresie korzystania z poszczególnych instrumentów WPR. Zdecydowanie najmniejszą produktywnością cechowały się kraje postkomunistyczne, nienależące do UE. Na taki stan rzeczy wpłynęły czynniki ekonomiczne i polityczne, a więc głównie brak kapitału na modernizację sektora. Nie bez znaczenia był też z pewnością brak presji demograficznej.

Jednym z ważniejszych wymiarów bezpieczeństwa żywnościowego jest dzienna konsumpcja energii pochodzącej z produktów spożywczych. Nie jest to oczywiście miara ostateczna, gdyż nie uwzględnia stopnia zróżnicowania tego zjawiska wewnątrz społeczeństwa, w tym szczególnie odsetka osób niedożywionych. W powiązaniu z produktywnością rolnictwa wskazuje jednak, na ile sektor ten realizuje swoją podstawową funkcję. Największy przeciętny poziom konsumpcji w całym okresie wystąpił w krajach UE-15. Jego stabilność na tak wysokim poziomie wynikała wprost $\mathrm{z}$ istoty biologicznego przymusu konsumpcji, której maksymalna wielkość jest limitowana potrzebami i możliwościami ludzkiego organizmu. W tym kontekście instrumenty WPR nakierowane na stabilizację lub ograniczenie

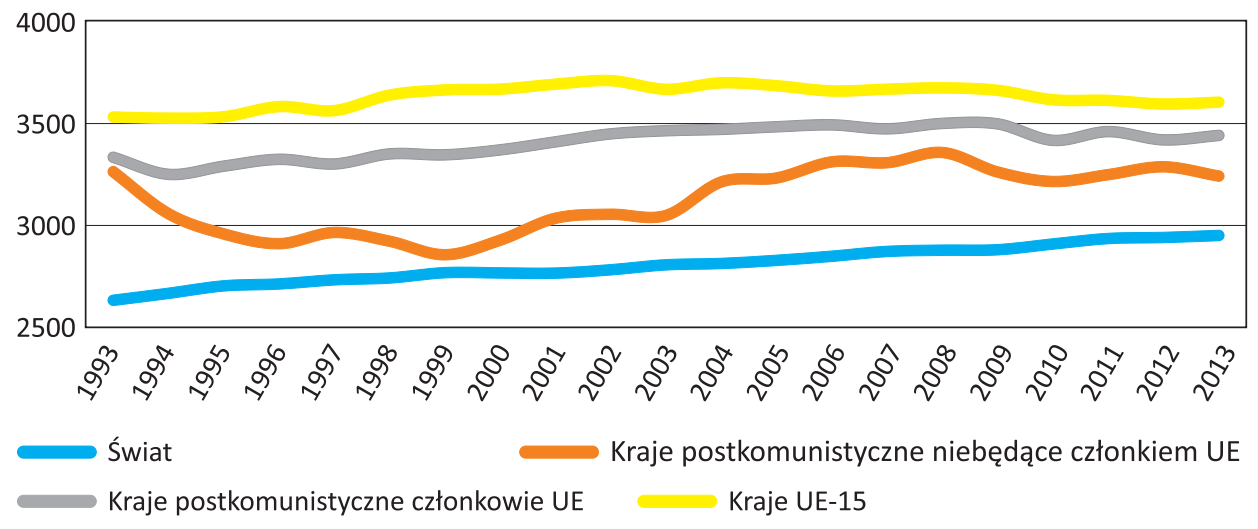

Rysunek 5. Spożycie energii (kcal/os./dzień)

Figure 5. Consumption of energy (kcal/pers./day)

Źródło: obliczenia własne na podstawie faostat.fao.org.

Source: Own calculation based on faostat.fao.org. 
produkcji rolniczej wydają się uzasadnione. Niewiele mniejszą konsumpcją cechują się postkomunistyczne kraje UE-12, z tym tylko, że tam nastąpił niewielki wzrost, co może wskazywać na ogólną poprawę sytuacji wyżywieniowej w okresie po upadku socjalizmu. Inna sytuacja wystąpiła w krajach postkomunistycznych, niebędących członkami UE. Tam w drugiej połowie lat 90. nastąpił dość znaczący spadek przeciętnej konsumpcji, a następnie wzrost do poziomu krajów UE-12. Zmiany te bardziej można wiązać z poziomem zamożności poszczególnych krajów i przemianami całej gospodarki niż ze stanem rolnictwa. Kraje, które w latach 90. po upadku komunizmu nie przystąpiły do UE, są jednocześnie tymi, które nie przeprowadziły reform rynkowych, co ostatecznie skutkowało większą niestabilnością ekonomiczną, przejawiającą się między innymi poziomem konsumpcji żywności. Warto jednak zauważyć, że we wszystkich analizowanych grupach dzienne spożycie energii jest wyższe od poziomu światowego.

\section{Oddziaływanie rolnictwa na środowisko}

Rolnictwo oddziałuje na środowisko na wiele sposobów. Najważniejszym i historycznie pierwotnym jest przekształcenie krajobrazu i tworzenie sztucznych siedlisk, jakimi są agroekosystemy. W niniejszym opracowaniu jako miernik przyjęto natomiast ilość emitowanych gazów cieplarnianych. Podejście takie wynikało z globalnego charakteru oddziaływania emisji oraz z tego, że jest to parametr jednoznacznie zdefiniowany, o dość dobrze sprecyzowanym charakterze i oddziaływaniu, a więc mogący stanowić syntetyczną miarę wpływu produkcji rolniczej na środowisko. Jednostkowe emisje w przeliczeniu na ha UR (rys. 6) wskazują na podstawową prawidłowość ekonomiczną, zakładającą istnienie ścisłego związku pomiędzy wielkością produkcji i ponoszonych na nią nakładów. Odnosi się to nie tylko do wartości monetarnych, ale ma także swój wymiar naturalny, w tym odnoszący się do interakcji ze środowiskiem. Zasadniczo wielkość emisji w poszczególnych grupach odpowiada produktywności ziemi (rys. 4), z tym tylko, że kraje postkomunistyczne niebędące członkami UE w pierwszych latach analizy uzyskiwały wielkość wyższą od średniej światowej. Spadek, szczególnie zauważalny $\mathrm{w}$ tej grupie w latach 90., wiązać należy z przemianami agrarnymi i gospodarczymi, skutkującymi między innymi koniecznością ograniczenia (racjonalizacji) stosowania przemysłowych środków produkcji. Był to jednak pozytywny efekt uboczny dokonanych przemian gospodarczych, a nie skutek prowadzonej polityki prośrodowiskowej. Poza tą grupą wszędzie przez cały badany okres daje się zauważyć względną stabilność, która wynika z braku konieczności wzrostu intensywności produkcji. Przestrzenna i czasowa zbieżność zjawiska produktywności ziemi i wielkości emisji, z jednej strony jest zrozumiała z ekonomicznego punktu 
widzenia, a z drugiej skłania do konstatacji, że zaspokojenie potrzeb żywnościowych danej populacji musi się wiązać z ponoszeniem proporcjonalnych kosztów, także tych o charakterze środowiskowym. Rolą polityki oraz nauk rolniczych (głównie technologii oraz hodowli i genetyki) jest ich zminimalizowanie, a więc poprawa środowiskowej efektywności gospodarowania.

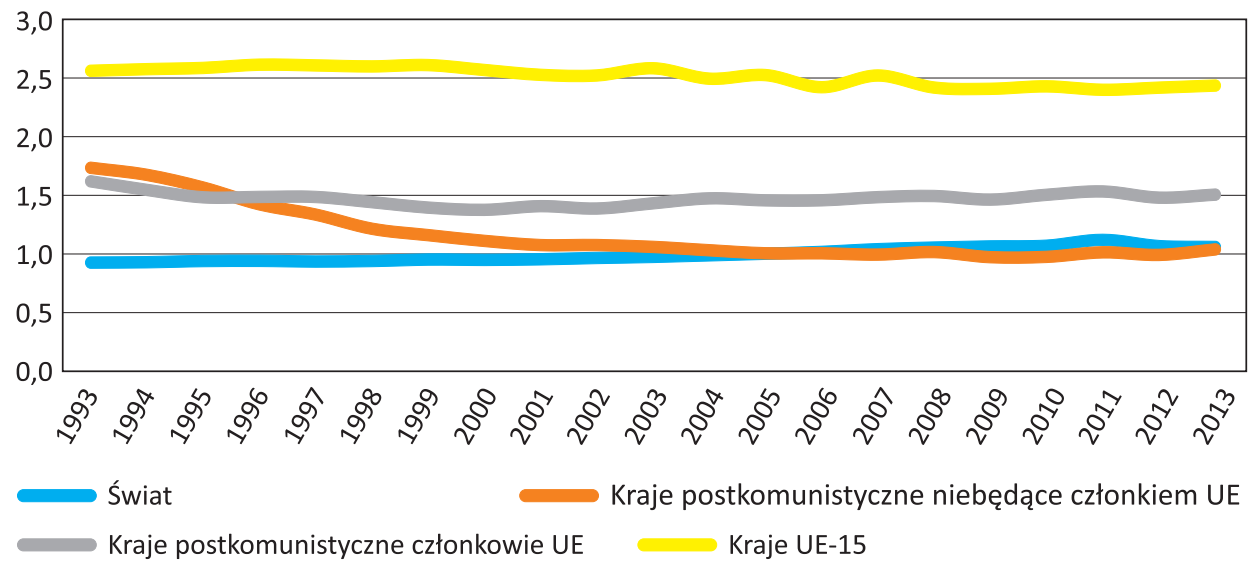

Rysunek 6. Emisja rolniczych gazów cieplarnianych (t/ha UR)

Figure 6. Emission of agricultural greenhouse gases ( $t / h a$ UAA)

Źródło: obliczenia własne na podstawie faostat.fao.org.

Source: Own calculation based on faostat.fao.org.

Pomimo obserwowanej ogólnie stabilności jednostkowej produktywności oraz wielkości emisji, cechującej większość badanych grup, widoczne są pewne zmiany środowiskowej efektywności gospodarowania, rozumianej jako relacja pomiędzy ilością wytwarzanych kilokalorii i wyemitowanych gazów cieplarnianych (rys. 7).

Największy postęp dokonał się w krajach postkomunistycznych nienależących do UE. Jest to o tyle zaskakujące, że nie funkcjonuje tam rozbudowany na kształt WPR system uregulowań nakierowanych na cele środowiskowe, $\mathrm{w}$ tym na gospodarkę niskoemisyjną. Co więcej, jest to zasadniczo sprzeczne z wynikami uzyskanymi w skali świata (Sadowski 2017), gdzie najbardziej wydajne środowiskowo było rolnictwo w krajach produkujących intensywnie, $\mathrm{w}$ tym w państwach europejskich (niekoniecznie należących do UE). Przyczyny rozbieżności są z pewnością złożone, aczkolwiek szukać ich należy głównie w specyfice rolnictwa krajów postkomunistycznych, które nie musiały dostosować się do standardów Unii Europejskiej, a więc także konieczności spełniania wymogów konkurencyjności. Nie bez znaczenia jest też z pewnością wpływ dominujących technik wytwórczych, w tym większej pracochłonności, co w pewnym stopniu odnosi się także do rolnictwa krajów UE-12. 


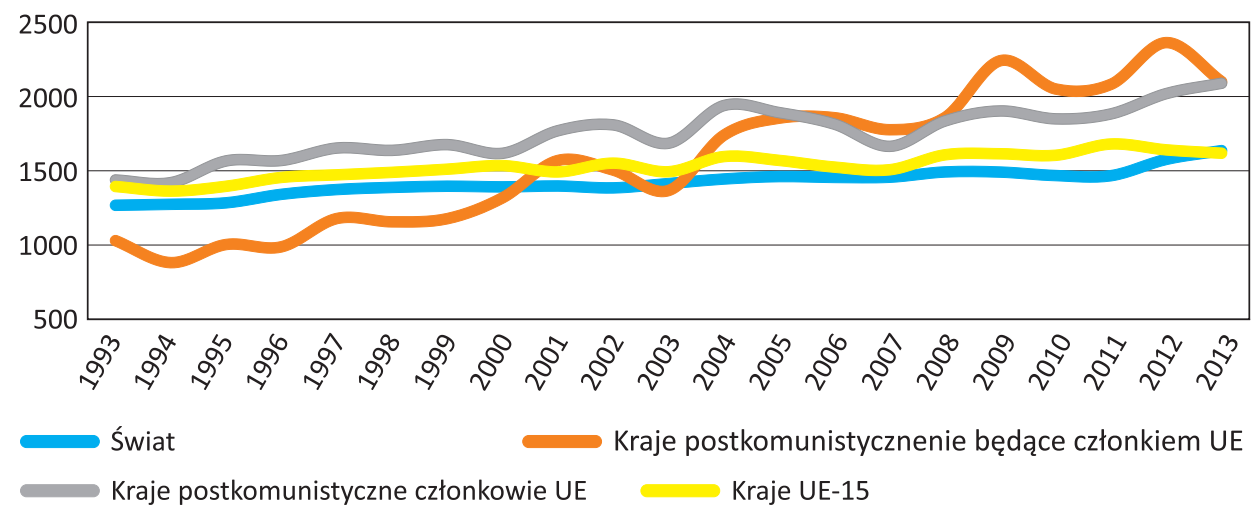

Rysunek 7. Efektywność środowiskowa rolnictwa (kcal/kg $\left.\mathrm{CO}_{2} \mathrm{eq}\right)$

Figure 7. Environmental efficiency of agriculture ( $\mathrm{kcal} / \mathrm{kg} \mathrm{CO} e \mathrm{eq})$

Źródło: obliczenia własne na podstawie faostat.fao.org.

Source: Own calculation based on faostat.fao.org.

Znaczącą rolę odegrały też wspomniana konieczność ograniczenia stosowania przemysłowych środków produkcji, będąca skutkiem przemian własnościowych i urealnienia relacji cenowych po upadku socjalizmu. Kapitałochłonne techniki dominujące z kolei w krajach UE-15 sprzyjają wysokiej produktywności i generują jednocześnie wysokie emisje. To jest zrozumiałe na gruncie prawideł ekonomii. Mniej jednoznaczne jest to, że nie przyczyniają się do wysokiej środowiskowej efektywności, co mogłyby sugerować przytoczone wyniki ogólnoświatowe. Przyczyna może tkwić właśnie w dużym (nadmiernym) udziale kapitału w produkcji rolnej krajów UE-15, co przekłada się na znaczne zużycie nieodnawialnych źródeł energii, a więc $\mathrm{w}$ efekcie i na emisje. Co równie interesujące, kraje UE-12, które w okresie przed-i poakcesyjnym musiały dostosować się do warunków konkurencyjności na wspólnym rynku, poprawiły swoją efektywność środowiskową. To także złożone zjawisko, aczkolwiek w pewnym przynajmniej zakresie rozwiązania można szukać w działaniu instrumentów WPR i to niekoniecznie tych nakierowanych na kwestie środowiskowe. Możliwość modernizacji gospodarstw, szczególnie większych towarowych, usprawniła poszczególne technologie produkcji, nie tylko przyczyniając się do poprawy sytuacji mikroekonomicznej, ale także usprawniając relacje na linii rolnictwo-środowisko. Stagnacja efektywności środowiskowej w krajach UE-15 może w pewien sposób wskazywać na fiasko prośrodowiskowych celów WPR, szczególnie w obszarze gospodarki niskoemisyjnej. Trzeba jednak zwrócić uwagę, że kwestie klimatyczne w sposób szczególny wyartykułowane zostały dopiero w perspektywie 2014-2020, tak więc rzeczywiste efekty (lub ich brak) pojawią się dopiero w przyszłości. Niemniej przykład krajów postkomunistycznych, które nie 
przystąpiły do UE, wskazuje, że możliwości poprawy w zakresie oddziaływania rolnictwa na środowisko należy szukać nie tylko w rozwiązaniach politycznych i regulacjach prawnych. Pozostawiając problem otwarty do dalszych badań tego złożonego zjawiska, warto zwrócić uwagę na kilka, wydaje się zasadniczych, kwestii. Przede wszystkim pozytywnych efektów można spodziewać się w przypadku zbieżności interesów mikroekonomicznych i społecznych. W tym kontekście warto zaznaczyć, że poprawa efektywności rozumianej jako polepszenie relacji efektu do nakładu może mieć podobny przebieg w wielkościach nominalnych jak naturalnych, a więc redukcja kosztów wytwarzania przekłada się na zmniejszenie oddziaływania na środowisko. Do tego niezbędne jest między innymi wypracowanie przez naukę nowych technik wytwórczych, co w długiej perspektywie może mieć większy skutek niż regulacje nakazujące stosowanie odpowiednich praktyk w ramach istniejących technologii. Oczywiście nie oznacza to całkowitego deprecjonowania polityki, która może i powinna regulować relacje pomiędzy produkcją rolniczą a środowiskiem, także w obszarach nieobjętych niniejszą analizą. Chodzi raczej o odpowiednie rozłożenie akcentów i poszukiwanie niezauważalnych dotychczas czynników, poprawiających środowiskową efektywność gospodarowania.

\section{Podsumowanie}

Przeprowadzone badania wskazały na dominujące znaczenie czynników demograficznych i przyrodniczych na produktywność rolnictwa. Czynniki polityczne, takie jak zmiana ustroju czy akcesja do UE, miały znaczenie, aczkolwiek ich rola była mniejsza. Oczywiście należy mieć na uwadze, że dylematy dotyczące relacji między rolnictwem i środowiskiem dalece wykraczają poza zarysowane w niniejszym opracowaniu zależności. Niemniej jednak opisany stan rzeczy wskazuje na strategiczną funkcję rolnictwa jako sektora zaspokajającego podstawowe potrzeby społeczne, które musi funkcjonować na odpowiednim poziomie przy różnych uwarunkowaniach politycznych i ekonomicznych. Rozpatrując problem na najbardziej ogólnym poziomie, zauważyć można, że wszystkie analizowane grupy cechowały się względną stabilnością demograficzną, co przekładało się na stabilność produkcji, rozumianej jako ilość wytwarzanych kilokalorii. Co równie istotne, w skali globalnej analizowane grupy różnią się od reszty świata, gdzie presja demograficzna była znaczna. W długiej perspektywie oznacza to, że zjawiska dokonujące się na tym kontynencie (zarówno w jego zachodniej, środkowej, jak i wschodniej części) nie zawsze są zbieżne z tym, co dzieje się w innych częściach globu. Rzecz odnosi się także do rolnictwa.

Nie oznacza to jednak, że nie należy z uwagą przyglądać się sukcesom i porażkom europejskiego rolnictwa. Przede wszystkim stanowi ono (mimo wielu swoich wad) swoisty wzór, pokazujący, że możliwe jest zapewnienie bezpieczeństwa 
żywnościowego przy zachowaniu satysfakcjonujących parametrów środowiskowych. Nawet bowiem stagnacja efektywności środowiskowej w krajach UE-15 dokonała się na poziomie wyższym od średniej światowej, przy jednoczesnej wysokiej produktywności oraz przy równie wysokim i stabilnym bezpieczeństwie żywnościowym. Poprawa efektywności w krajach postkomunistycznych niebędących członkami UE powinna natomiast stanowić przyczynek do rozważań nad pozapolitycznymi czynnikami determinującymi zrównoważenie środowiskowe, $\mathrm{w}$ tym wpływem czynników rynkowych. Oczywiście zagadnienie to nie powinno być analizowane w oderwaniu od zasadniczej funkcji rolnictwa, jaką jest produkcja żywności. W poczynionych uwagach podkreślono znaczenie relacji pomiędzy zaangażowaniem czynników praca i kapitał. Z jednej strony analizy dokonane w skali świata (Sadowski 2017) wskazywały na niską efektywność środowiskową (i jednocześnie niską i niestabilną produktywność) systemów tradycyjnych, z drugiej, w niniejszym opracowaniu zauważono, że kapitałochłonne systemy w krajach UE-15 są mniej efektywne niż w krajach UE-12. Oznacza to potrzebę poszukiwania optymalnych rozwiązań, co jest sprawą o tyle niełatwą, że relacje kapitał-praca w rolnictwie nie są do końca regulowalne przy zastosowaniu instrumentów politycznych. Co więcej, można spodziewać się, że gdyby zaistniała taka potrzeba, będzie niezwykle trudno nakłonić społeczeństwa krajów wysokorozwiniętych do zwiększenia udziału osób zaangażowanych w produkcję rolniczą. Nie przesądzając więc sprawy, można mniemać, że odpowiednich rozwiązań, poprawiających oddziaływanie rolnictwa na środowisko (w tym na klimat) poszukiwać trzeba będzie głównie w postępie naukowo-technicznym, przy zmniejszającej się roli uregulowań politycznych i prawnych. Jeśli uwzględni się, że gros badań w zakresie rolnictwa finansowanych jest ze środków publicznych, na problem można spojrzeć z nieco innej perspektywy: priorytety rolniczej polityki prośrodowiskowej powinny $\mathrm{w}$ większym stopniu uwzględniać działania na rzecz poszukiwania nowych rozwiązań technologicznych (które jednocześnie będą akceptowalne z mikroekonomicznego punktu widzenia), niż skłanianie producentów do stosowania odpowiednich praktyk w ramach istniejących technologii.

\section{Bibliografia}

Czyżewski A., Czyżewski B. (2016). Research challenges for agricultural economics in the new paradigm. W: B. Czyżewski (red.). Political Rents of European Farms in Sustainable Development Paradigm: International, National and Regional Perspective (s. 18-27). Warszawa: Wydawnictwo Naukowe PWN.

Dzun W., Tereszczuk M. (2009). Rolnictwo Rosji, Ukrainy i Białorusi w procesie transformacji w latach 1990-2007. Warszawa: Instytut Ekonomiki Rolnictwa i Gospodarki Żywnościowej - PIB. 
Halamska M. (1998). Dekolektywizacja rolnictwa w Europie Środkowo-Wschodniej i jej konsekwencje. Warszawa: Instytut Rozwoju Wsi i Rolnictwa PAN.

Jankowska A. (2016). Typologia rolnictwa krajów kandydujących do Unii Europejskiej ze względu na wybrane cechy sektora rolnego. Zeszyty Naukowe Szkoły Głównej Gospodarstwa Wiejskiego w Warszawie. Problemy Rolnictwa Światowego, 16 (2), 145-153.

Majerova V., Sálus J., Stieva T., Valcheva E. (2016). Economic and social preconditions of development in the Czech rural areas: Acceleration of global influence and local changes. W: A. Kowalski, M. Wigier, B. Wieliczko (red.). Ekonomia versus środowisko konkurencyjność czy komplementarność (s. 87-100). Warszawa: Instytut Ekonomiki Rolnictwa i Gospodarki Żywnościowej - PIB.

Poczta W., Baer-Nawrocka A. (2016). The sustainability of agriculture in the European Union against a global backdrop. W: B. Czyżewski (red.). Political Rents of European Farms in Sustainable Development Paradigm: International, National and Regional Perspective (s. 60-68). Warszawa: Wydawnictwo Naukowe PWN.

Poczta W., Sadowski A., Średzińska J. (2008). Rola gospodarstw wielkotowarowych w rolnictwie Unii Europejskiej. Roczniki Nauk Rolniczych. Seria G - Ekonomika Rolnictwa, 95 (1), 42-56.

Rowiński J. (2011). Wsparcie rolnictwa w wybranych krajach. Warszawa: Instytut Ekonomiki Rolnictwa i Gospodarki Żywnościowej - PIB.

Sadowski A. (2009). Gospodarstwa rolne w koncepcji polityki zrównoważonego rozwoju obszarów wiejskich. Journal of Agribussines and Rural Development, 2 (12), 167-173.

Sadowski A. (2012). Zrównoważony rozwój gospodarstw rolnych z uwzględnieniem wpływu Wspólnej Polityki Rolnej Unii Europejskiej. Poznań: Uniwersytet Przyrodniczy w Poznaniu.

Sadowski A. (2017). Wyżywieniowe i środowiskowe funkcje światowego rolnictwa: Analiza ostatniego półwiecza. Poznań: Uniwersytet Przyrodniczy w Poznaniu.

Sadowski A., Czubak W. (2012). Zakres i instrumenty polityki rolnej stosowane w różnych systemach społeczno-ekonomicznych w Polsce. W: W. Czubak, E. Kiryluk-Dryjska, W. Poczta, A. Sadowski (red.). Wspólna Polityka Rolna a rozwój rolnictwa w Polsce (s. 41-54). Poznań: Uniwersytet Przyrodniczy w Poznaniu.

Sadowski A., Czubak W. (2013). The priorities of rural development in the EU countries in years 2007-2013. Agricultural Economics, 59 (2), 58-73.

Sadowski A., Poczta W., Beba P., Szuba-Barańska E. (2016). Zróżnicowanie produktywności modeli gospodarstw rolnych w UE. Wieś i Rolnictwo, 1 (170), 127-138.

Sadowski A., Poczta W., Szuba-Barańska E., Beba P. (2015). Modele gospodarstw rolnych w państwach Unii Europejskiej. Wieś i Rolnictwo, 3 (168), 43-62.

Szpak J. (2007). Historia gospodarcza powszechna. Warszawa: Polskie Wydawnictwo Ekonomiczne.

Tudor M. (2016). Resilience of Romanian agriculture: An overview. W: A. Kowalski, M. Wigier, B. Wieliczko (red.). Ekonomia versus środowisko - konkurencyjność czy komplementarność (s. 150-159). Warszawa: Instytut Ekonomiki Rolnictwa i Gospodarki Żywnościowej - PIB. 


\title{
Food Security and Environmental Impact of Agriculture in the European Transition Economies
}

\begin{abstract}
This paper deals with the problem of relations between agriculture and environment, considered in the context of political changes that took place in Central and Eastern Europe. Against the background of general considerations on the significance of natural and anthropogenic factors (including mainly politics), the research refers to the European post-communist countries, some of which joined the EU, and some being still outside the group. Research results were compared with the corresponding values for EU-15 Member States and the average values for the World. The analysis covered the period between 1993-2013, i.e. the years of the undisturbed existence of the countries concerned. Using the original methodology, we identified changes in the productivity of agriculture (understood as the amount of agricultural energy produced per $1 \mathrm{ha}$ ) and agriculture's impact on the environment, estimated as the amount of greenhouse gas emissions. Results of the analysis proved that demographic and natural factors had an essential impact on the intensity of agricultural production and the scale of greenhouse gas emissions. The possibility to achieve food security depended on the technologies used, and indirectly on the level of the country's economic development. Attention was paid to a different approach to the development of agriculture in the transition countries which are EU Member States and those which are not. With regard to the environmental sustainability, the greatest progress has been made by the transition countries which did not join the EU. Within this context, we considered some non-political factors shaping the relationship between agriculture and environment.
\end{abstract}

Keywords: European transition economies, food security, sustainable development of agriculture, CAP. 